\title{
Epidemiology of viral hepatitis in the Republic of Congo: review
}

\author{
Laure Stella Ghoma Linguissi ${ }^{1 *}$ and Celine Nguefeu Nkenfou ${ }^{2,3}$
}

\begin{abstract}
Objective: Considered an endemic zone, Republic of Congo has a high seroprevalence rate of hepatitis B and C virus. To know the extent of hepatitis infection as a public health problem, we reviewed published literature and other sources for reports of these viral infections in the country.

Results: High seroprevalence of HBV and HCV carriage in blood donors were observed in studies confirming Congo's place in the hyperendemic area of HBV and HCV infection. These prevalence were compared by Chi square test. We compared the prevalence of three studies conducted in 1996, 2015 and 2016. The statistical results were very significant. HBV genotype E was most prevalent. Very few studies were done on pregnant women. Difficulties in the care and management of patients were also noted because of the high cost of often unavailable treatments. Difficulties arise, however, when an attempt was made to implement the National Hepatitis Control Program. Despite studies conducted on hepatitis prevalence, health interventions are still needed to care and manage these patients and the need to implement the national hepatitis control is more pressing in the Congo.
\end{abstract}

Keywords: Hepatitis B virus (HBV), Hepatitis C virus (HCV), Republic of Congo

\section{Introduction}

Viral hepatitis is caused by five types of viruses (A, B, C, D and E) that are transmitted differently [1]. Type A and $E$ are transmitted through food and water [2]. Infection with these viruses can lead to epidemic outbreaks of hepatitis in populations without safe drinking water and in poor sanitation conditions [3-5]. These two types of hepatitis (A and E) do not cause infection or chronic liver disease and do not require specific treatment $[6,7]$. Types $\mathrm{B}$ and $\mathrm{C}$ are infections transmitted by blood during injection or medical interventions performed in poor sanitary conditions [8-11]. Hepatitis B virus is also transmitted sexually [12-14]. There is also transmission from mother to the child [15-18] which turns out to be the most important in the Congo, where pregnant women were found with significant proportions of hepatitis markers $[19,20]$.

\footnotetext{
*Correspondence: linguissi@gmail.com

1 Institut National de Recherche en Sciences de la Santé, Brazzaville,

République du Congo

Full list of author information is available at the end of the article
}

Considered an endemic zone, Congo has a high seroprevalence rate of hepatitis $C$ virus. A study conducted in 2014 among 17,351 blood donors, in the two major cities of the country revealed that the relative frequency was $4.1 \%$ in Brazzaville and $4.3 \%$ in Pointe-Noire [21]. At Brazzaville, the seroprevalence rate among 1363 blood donors was documented to be $9.9 \%$. Hepatitis B infection remains also a public health problem in Congo [22].

To appreciate the extent of hepatitis infection as a public health problem in Republic of Congo, we reviewed published literature and other sources for reports of viral hepatitis in the country. The objective of this review is to report the overall prevalence of viral hepatitis in the Republic of Congo.

\section{Methods \\ Main text}

Although there is no comprehensive report on viral hepatitis in ROC, all studies focusing on hepatitis in the ROC have been considered. PubMed database was used to retrieve research articles about viral hepatitis in ROC. The search terms were: (“"hepatitis"[MeSH Terms] OR "hepatitis"[All Fields] OR "hepatitis a"[MeSH Terms] OR 
"hepatitis a"[All Fields]) AND ("congo"[MeSH Terms] OR "congo"[All Fields])) NOT (Democratic [All Fields] AND Republic [All Fields] AND ("congo" [MeSH Terms] OR "congo"[All Fields]).

\section{Criteria of inclusion}

This review considered full articles and abstracts published in peer review journals between 1952 up to 2016 which have reported incidence and prevalence of viral hepatitis in Republic of Congo.

\section{Target population}

Most studies on hepatitis in the Republic of Congo reported on blood donors. So our conclusion will be made based on blood donors.

\section{Strategy}

Data were extracted and verified in full by one author (GLLS) on the following: country, year of publication, year of collection; study type, study design, biomarkers tested, study population, sample size, proportion male, age, HCV seroprevalence, PCR test based prevalence, genotype, subtypes.

\section{Analysis data}

After collecting the related information, the data were transferred into the computer and analyzed by EpiInfo version 7.1.1. Data were analyzed using descriptive statistical methods, Chi square and correlation at a significant level of $<.05$.

\section{Results}

We retrieved 16 research articles from the PubMed database. We excluded 7 articles from this review because their content did not mention any subtype. Table 1 summarizes the description of studies on hepatitis in the Republic of Congo.

\section{Localisation of studies}

Most of the studies were conducted in Brazzaville and Pointe-Noire and one study was conducted in several localities: Niari, Bouenza, Lekoumou among ethnic groups (Bantu et Pygmy) [23].

\section{Hepatitis: a public health concern}

In Congo, many people carry the virus B and/or C [1922]. However, most of them are unaware of this, believing that the only chronic viral disease is HIV/AIDS [24, 25]. This situation is exacerbated by the lack of a response strategy that incorporates specific awareness-raising actions [26-28]; co-infection with hepatitis viruses and HIV/AIDS [29], the low or non-existence of immunization coverage against the $B$ virus [30-33] or a lack of knowledge of HIV status, even among health workers $[34,35]$. In addition, the difficulties in caring and management of patients were also noted because of the high cost of often unavailable treatments. Vaccines are available to prevent hepatitis B at a cost of 27,000 FCFA for adults and 9000 FCFA for the child for three doses [36], vaccination is the best way to get immunity to these viruses [37-40].

Effective drugs are available, but treatment remains inaccessible to many patients because of its high cost. In the Republic of Congo, hepatitis $C$ treatment costs about one million FCFA per month and lasts at least 1 year. For hepatitis $\mathrm{B}$, there is no treatment as such in the country. Treatment is now being done using antiretrovirals for HIV control that also act on hepatitis B [41, 42]. The screening costs is currently 30,000 FCFA and the full biological testing is of the order of 450,000-500,000 FCFA [36].

\section{Epidemiology of viral hepatitis Hepatitis B}

The high incidence of HBsAg carriage in blood donors was observed in the Pointe-Noire, Niari and Bouenza departments, confirming Congo's place in the hyperendemic area of HBV infection. Atipo-Ibara et al. [22] in their study observed the frequence of HBsAg carriage in blood donors in few localities of the country: PointeNoire (10.8\%), Nkayi (9.3\%), Dolisie (8.9\%), Madingou (5.9\%) and Mouyondzi (5.2\%) [22].

Angounda et al. [19] indicated a prevalence of HBeAg was 15.3 and $73 \%$ of patients were anti-HBe positive. In this study Angounda et al. detected the Chronic HBV among 111 patients at high risk of hepatitis disease progression. And the presence of $\mathrm{HBeAg}$ was high in chronic active hepatitis $(\mathrm{CAH})(41.18 \%)$ and $\mathrm{HBeAb}$ positive was higher in the age group 39-45 year with a prevalence of $56.7 \%$ [43].

The prevalence of serological markers of hepatitis B was higher in the study of Angounda et al. among 648 blood donors in Brazzaville, which confirms the high risk of blood transfusion [44]. Over all, although the prevalence of hepatitis B was different from one study to another (see Table 2), this prevalence especially for HBsAg was above $6 \%$, which is considered high.

\section{Hepatitis C}

Central Africa is considered as a high-prevalence region of anti-HCV antibodies, detected in about $2-20 \%$ of the population [45-47]. In ROC, HCV seroprevalence studies have been conducted among blood donors [23, 48, 49] or carried out among the Bantu and Pygmy populations. And HCV seroprevalence was lower in Pygmies (3.8\%) [23]. The similarly study demonstrated a low prevalence 


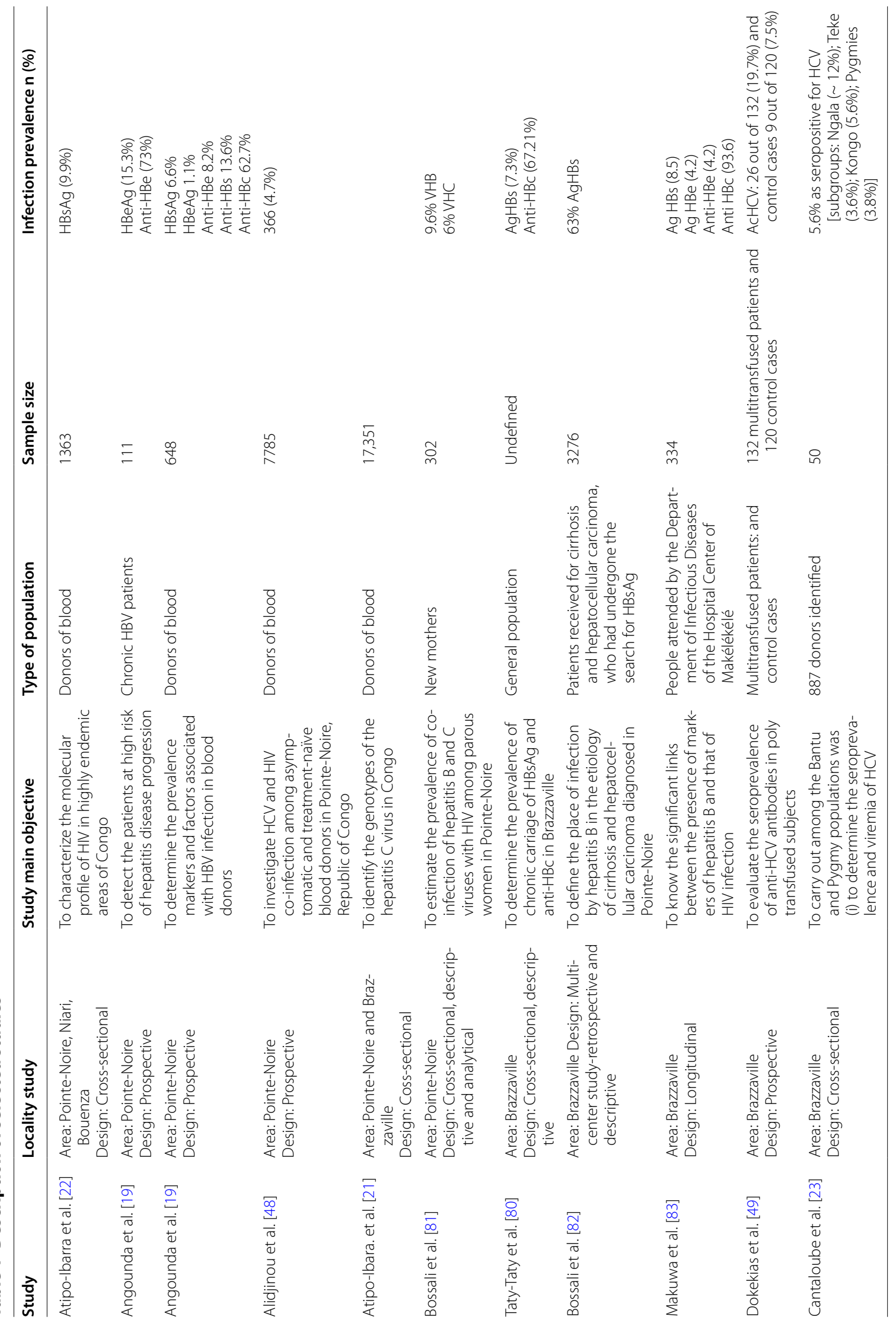


Table 2 Summary of the prevalence of hepatitis B according to selected studies and biomarkers

\begin{tabular}{|c|c|c|c|c|}
\hline Study & Sample size & HBsAg prevalence, $n(\%)^{*}$ & Anti-HBe prevalence, $n(\%)^{\mu}$ & Anti-HBc prevalence, $n(\%)^{\#}$ \\
\hline Atipo-Ibarra et al. [22] (1) & 1363 & 9.9 & & \\
\hline Angounda et al. [43] (2) & 648 & 6.6 & 8.2 & 62.7 \\
\hline Makuwa et al. [83] (3) & 334 & 8.5 & 4.2 & 93.6 \\
\hline
\end{tabular}

$p$ value: $p(1) \rightarrow(2)<0.0192 ; p(1) \rightarrow(3)<0.5^{*} ; p(2) \rightarrow(3)<0.026^{\mu} ; p(2) \rightarrow(3)<0.00000^{\#} ; p(2) \rightarrow(3)<0.29^{*}$

of $\mathrm{HCV}$ infection among pygmies living in Cameroon [50].

In the previous study conducted in 2014 in PointeNoire, seroprevalence of anti-HCV antibodies in the blood donors has been reported to 4.7\% [48].

The last study conducted among adults in one HIV clinic in the capital, Brazzaville in 2010, showed that the prevalence of $\mathrm{HCV}$ antibody was $5.7 \%$. Studies have revealed that the majority of $\mathrm{HCV}$ positive patients were predominantly male $[21,51]$.

The key problem with this explanation is that generally, blood donors are male [52] and there are multiple restrictions for blood donation by women [53], which are linked either to breastfeeding [54, 55], menstruation [56] or pregnancy [57].

\section{Genotyping of hepatitis \\ Hepatitis B}

In the single study on the genotyping of hepatitis B in the Republic of Congo, 82 samples out of 111 (73.9\%) were genotyped in the HBV S region. Of these, 58 (70.7\%) subjects were infected with HBV genotype E and 24 (29.3\%) were infected with HBV genotype A. Previously in Cameroon, the two prevalent genotypes identified were $69.6 \%$ HBV genotype $\mathrm{E}$ and $30.4 \% \mathrm{HBV}$ genotype $\mathrm{A}$ among the HIV-1 infected patients [58]. HBV genotype E was also the most prevalent genotype in Angola, found in 87.5\%, followed by genotype A in 10\% [59]. Genotypes E and A are the most prevalent among blood donors in areas of high endemicity [43].

\section{Hepatitis $C$}

In the study conducted by Cantaloube et al. in 2010, the genotyping was performed through amplification and sequencing of a $339 \mathrm{pb}$ amplicon located from position 8370 to 8708 in the NS5b region and a 357-nucleotide sequence located from position 1029 to 1385 in the E1 region. The results of this study showed 21 strains belonged to characterized subtypes, that is $4 \mathrm{c}$ in 8 $(25.8 \%), 4 \mathrm{~h}$ in $2(6.5 \%), 4 \mathrm{k}$ in $3(9.7 \%)$, and $4 \mathrm{r}$ in $8(25.8 \%)$ [23]. The most common subtypes were $4 \mathrm{c}$ and $4 \mathrm{r}$. All these subtypes were identified in a study conducted in DRC [60].
Atipo-ibara et al. used only the NS5B region, they obtained sequencing of 17 samples, 16 genotypes 4 (G4) and 1 genotype 2 (G2) [22]. The distribution of genotype 4 subtypes in this article shows great genetic diversity and predominance of one subtype G4. The epidemic history of HCV subtype $4 \mathrm{c}$ and $4 \mathrm{r}$ slowed considerably [23]. Similarly genetic diversity has been observed in Kinshasa in DRC by Iles et al. in 2013 and 2015 [60-62]. Zeba et al. in 2014 in Burkina Faso observed that HCV genotype 4 was the least frequent among the blood donors [63].

\section{Risk factors for hepatitis B and C}

Blood transfusion remains the most important mode of transmission of hepatitis $C[64,65]$. In the Republic of Congo, Elira et al. in 2003 reported the seroprevalence of anti-HCV antibodies among 252 multitransfused patients to be $1.7 \%$ [49]. In one of their previous study they observed a prevalence of $6.7 \%$ of anti-HCV antibodies in blood donors [51]. Atipo Ibara et al. in 2013 on the other side indicated that blood transfusion was a risk factor in 143 donors out of a total of 1363 (10.5\%) donors [22].

Thus, such as HIV/AIDS, hepatitis $\mathrm{C}$ is a major concern in blood transfusion services that requires mandatory pre-transfusion screening $[49,66]$. ELISA is the most common routine test for hepatitis C screening [67-69]. The risk of false positive reactions that are due to crossreactions with other viruses is very common $[70,71]$.

\section{Global response: implementation of the national program for the control of viral hepatitis $B$ and $C$}

A strategic plan was drawn for 2016-2021 and has to be implemented [72, 73]. It focuses on public awareness and prevention as well as access to safe, affordable and effective care and treatment $[74,75]$. One of the goals of this strategy is to reduce the number of new cases of chronic hepatitis by $30 \%$ by 2020 and $90 \%$ by $2030[76,77]$ and to reduce mortality rates due to hepatitis $B$ and $C$ by $10 \%$ by 2020 and by $65 \%$ by 2030 [78].

So far in the Congo, a short term national program for the control of viral hepatitis B and C drawed since 2014 could not assure affordability of drugs and the care of patients remained very costly in the country $[36,79]$. The national program will be responsible for regular supply 
of medicines biological tests necessary for the care and management of patients suffering from hepatitis. This program will play an important role in the collection of statistical data in the Republic of Congo.

Difficulties arise, however, when an attempt was made to implement the National Hepatitis Control Program. The few studies conducted in ROC showed that, there were the unmet needs for routine HBsAg screening and implementation of immunization against HBV as effective means to prevent hepatitis B [22]. New strategies must be developed to include routine screening of pregnant women and implementation of vaccination programs for newborns [43].

\section{Conclusion}

Hepatitis is a major health problem that requires greater attention in Republic of Congo.

Although prevalence vary from one study to another, this prevalence was high, above $6 \%$ for $\mathrm{HBsAg}$, one of the most reliable markers for hepatitis B infection. Also, genotype $B$ was the most prevalent. This review reports finding of significant public health importance revealing a high frequency of co-infection with $\mathrm{HBV} / \mathrm{HCV}$ in HIV infected individuals in Congo with risk factors for coinfection in the population. This review also stress that blood to be transfused should undergo systematic analyses in order to exclude viral infections including hepatitis.

\section{Limitations}

In this study we summarized insights of hepatitis virus; pathology which is not well explored in our country. This review based finding of previous studies; data incompleteness and poor document retention system were limitation of this study.

\section{Abbreviation}

HBV: Hepatitis B Virus; HCV: Hepatitis C Virus; ROC: Republic of Congo.

\section{Authors' contributions}

LSGL conceived of the idea for the paper and edited the draft extensively. CNN analysed the data, revised the manuscript. Both authors read and approved the final manuscript.

\section{Authors' information}

Laure Stella Ghoma Linguissi is Searcher at Institut National de Recherche en Sciences de la Santé (IRSSA), in Brazzaville. She led this review for looking for data on hepatitis in Republic of Congo.

My goal in developing this review was to assist my country in reaching its objectives public health in the development of National Hepatitis Program.

\footnotetext{
Author details

${ }^{1}$ Institut National de Recherche en Sciences de la Santé, Brazzaville, République du Congo. ${ }^{2}$ Chantal Biya International Reference Centre for Research on Prevention and Management on HIV and AIDS, Yaounde, Cameroon. ${ }^{3}$ Higher Teachers Training College, University of Yaounde I, Yaounde, Cameroon.
}

\section{Acknowledgements}

There was no source of funding for this manuscript. The authors would like to thank Dr. Mathew Bates for proofreading assistance.

\section{Competing interests}

The authors declare that they have no competing interests.

\section{Availability of data and materials}

The data that support the findings of this review are available from $[19,49]$ but restrictions apply to the availability of these data, which were used under license for the current study, and so are not publicly available. Data are however available from the authors upon reasonable request and with permission of Taty-Taty et al. (1990) and Atipo-lbara et al. [21, 22].

\section{Consent to publish}

Not applicable.

\section{Ethics approval and consent to participate}

The Ethics Committee for Health Sciences Research (CERSSA) has found that as it is a literary review study of previous research studies that had already obtained ethical approval it was not necessary to solicit a ethical approval. No participants' consent could be obtained, as it was a review study.

\section{Funding}

The authors alone are responsible for the content and writing of the paper They benefited from no source of funding or sponsorship, either from the public, private or not-for-profit sectors. The corresponding author had full access to all data in the study and had final responsibility to submit on behalf of all authors this manuscript for publication.

\section{Publisher's Note}

Springer Nature remains neutral with regard to jurisdictional claims in institutional affiliation.

Received: 3 October 2017 Accepted: 21 November 2017

Published online: 02 December 2017

\section{References}

1. Franca R, Silva L, Melo MC, Cavalcante S, Lima B, Rocha A, et al. Pediatric knowledge about acute viral hepatitis. Braz J Infect Dis. 2004;8:361-6.

2. Teshale EH, Hu DJ, Holmberg SD. The two faces of hepatitis E virus. Clin Infect Dis. 2010;51:328-34.

3. Franco E, Meleleo C, Serino L, Sorbara D, Zaratti L. Hepatitis A: epidemiology and prevention in developing countries. World J. Hepatol. 2012;4:68.

4. Hakim ST, Afaque F, Javed S, Kazmi SU, Nadeem SG. Microbial agents responsible for diarrheal infections in flood victims: a study from Karachi, Pakistan. Open J Med Microbiol. 2014;4:106-14.

5. Kamal SM, Mahmoud S, Hafez T, El Fouly R. Viral hepatitis A to E in South Mediterranean countries. Mediterr J Hematol Infect Dis. 2010. http:// www.mjhid.org/article/view/5424. Accessed 27 May 2017.

6. Matheny SC, Kingery Do JE. Hepatitis A. Am Fam Physician. 2012;86:1027-34

7. Péron JM. Hepatitis E virus infection and cirrhosis of the liver. Gastroenterol Hepatol. 2016;12(9):565-7.

8. Hosoglu S, Celen M, Geyik M, Soyoral Y, Kara I. Transmission of hepatitis $C$ by blood splash into conjunctiva in a nurse. Am J Infect Control. 2003:31:502-4.

9. Jafari S, Copes R, Baharlou S, Etminan M, Buxton J. Tattooing and the risk of transmission of hepatitis C: a systematic review and meta-analysis. Int J Infect Dis. 2010;14:e928-40.

10. Seo DH, Whang DH, Song EY, Han KS. Occult hepatitis B virus infection and blood transfusion. World J Hepatol. 2015;7:600

11. Yuen M-F, Ka-Ho Wong D, Lee C-K, Tanaka Y, Allain J-P, Fung J, et al. Transmissibility of hepatitis B virus (HBV) infection through blood transfusion from blood donors with occult HBV infection. Clin Infect Dis. 2011;52:624-32. 
12. Handsfield $\mathrm{HH}$. Hepatitis $A$ and $B$ immunization in persons being evaluated for sexually transmitted diseases. Am J Med. 2005;118:69-74.

13. Lin AWC, Sridhar S, Wong KH, Lau SKP, Woo PCY. Epidemiology of sexually transmitted viral hepatitis in human immunodeficiency viruspositive men who have sex with men in Asia. J Formos Med Assoc. 2015;114:1154-61.

14. Terrault NA, Dodge JL, Murphy EL, Tavis JE, Kiss A, Levin TR, et al. Sexual transmission of hepatitis $C$ virus among monogamous heterosexual couples: the HCV partners study. Hepatology. 2013;57:881-9.

15. Indolfi $G$, Azzari C, Resti M. Perinatal transmission of hepatitis $C$ virus. J Pediatr. 2013;163(1549-1552):e1.

16. Liu Y, Wen J, Chen J, Xu C, Hu Y, Zhou Y-H. Rare detection of occult hepatitis B virus infection in children of mothers with positive hepatitis B surface antigen. PLoS ONE. 2014;9:e112803.

17. Ranger-Rogez S, Alain S, Denis F. Hepatitis viruses: mother to child transmission. Pathol Biol (Paris). 2002;50:568-75.

18. Verghese VP, Robinson JL. A systematic review of hepatitis E virus infection in children. Clin Infect Dis. 2014:59:689-97.

19. Angounda BM, Bokilo Dzia A, Boumba LMA, Itoua C, Ahombo G, Moukassa D, et al. Prevalence of serologic markers and risk factors for hepatitis $B$ virus among pregnant women in Brazzaville. Congo Int J Sci Res IJSR. 2016:5:1907-12

20. Itoua-Ngaporo A, Sapoulou M, Ibara J, Iloki L, Denis F. Prevalence of hepatitis B viral markers in a population of pregnant women in Brazzaville (Congo). J Gynecol Obstet Biol Reprod. 1994;24:534-6.

21. Atipo-Ibara BI, Mimesse J, Bokilo-Dzia A, Deby-Gassaye Ahoui-Apendi C, Bossali F, et al. Virus de l'hépatite C: étude des génotypes au Congo (Brazzaville). J Afr Hépato-Gastroentérol. 2014;8:16-9.

22. Atipo-Ibara BI, Itoua-Ngaporo AN, Dzia-Lepfoundzou A, Ahoui-Apendi C, Deby-Gassaye C, Bossali F, et al. Virus de l'hépatite B au Congo (Brazzaville): séroprévalence et diversité génétique chez les donneurs de sang en zones hyper endémiques. J Afr Hépato-Gastroentérol. 2015;9:127-31.

23. Cantaloube J-F, Gallian P, Bokilo A, Jordier F, Biagini P, Attoui H, et al. Analysis of hepatitis C virus strains circulating in Republic of the Congo: HCV in Republic of the Congo. J Med Virol. 2010;82:562-7.

24. Kwak YE. Lack of awareness of hepatitis B infection status and risk of developing hepatic complications in the us population. Gastroenterology. 2017;152:S162.

25. Siddiqui MA, Ansari S, Alam Khan Q. Socio-Demographic profile of patients with hepatitis B and hepatitis $C$ infections at Maswasi, Uttar Pradesh. Middle East J Rehabil Health. 2017 (In Press). http://www.jrehabilhealth.com/?page=article\&article_id=44359. Accessed 29 May 2017.

26. Locarnini S, Hatzakis A, Chen D-S, Lok A. Strategies to control hepatitis B: public policy, epidemiology, vaccine and drugs. J Hepatol. 2015;62:S76-86.

27. Mesquita F, Santos ME, Benzaken A, Corrêa RG, Cattapan E, Sereno LS, et al. The Brazilian comprehensive response to hepatitis C: from strategic thinking to access to interferon-free therapy. BMC Public Health. 2016;16. http://bmcpublichealth.biomedcentral.com/articles/10.1186/s12889016-3784-4. Accessed 29 May 2017.

28. Shiferaw F, Letebo M, Bane A. Chronic viral hepatitis: policy, regulation, and strategies for its control and elimination in Ethiopia. BMC Public Health. 2016;16. http://bmcpublichealth.biomedcentral.com/articles/10.1186/s12889-016-3459-1. Accessed 29 May 2017.

29. de Oliveira SB, Merchan-Hamann E, Amorim LDAF. HIV/AIDS coinfection with the hepatitis B and C viruses in Brazil. Cad Saúde Pública. 2014;30:433-8.

30. Bekondi C, Zanchi R, Seck A, Garin B, Giles-Vernick T, Gody JC, et al. HBV immunization and vaccine coverage among hospitalized children in Cameroon, Central African Republic and Senegal: a cross-sectional study. BMC Infect Dis. 2015;15. http://bmcinfectdis.biomedcentral.com/articles/10.1186/s12879-015-1000-2. Accessed 29 May 2017.

31. Hennessey K, Mendoza-Aldana J, Bayutas B, Lorenzo-Mariano KM, Diorditsa S. Hepatitis B control in the World Health Organization's Western Pacific Region: targets, strategies, status. Vaccine. 2013;31:J85-92.

32. Musa B, Samaila A, Femi O, Borodo M, Bussell S. Prevalence of hepatitis B virus infection in Nigeria, 2000-2013: a systematic review and metaanalysis. Niger J Clin Pract. 2015;18:163.

33. Ropero Álvarez AM, Pérez-Vilar S, Pacis-Tirso C, Contreras M, El Omeiri N, Ruiz-Matus $C$, et al. Progress in vaccination towards hepatitis B control and elimination in the Region of the Americas. BMC Public Health.
2017;17. http://bmcpublichealth.biomedcentral.com/articles/10.1186/ s12889-017-4227-6. Accessed 29 May 2017.

34. Cherutich P, Kaiser R, Galbraith J, Williamson J, Shiraishi RW, Ngare C, et al. Lack of knowledge of HIV status a major barrier to HIV prevention, care and treatment efforts in Kenya: results from a nationally representative study. PLOS ONE. 2012;7:e36797.

35. Mohlabane N, Tutshana B, Peltzer K, Mwisongo A. Barriers and facilitators associated with HIV testing uptake in South African health facilities offering HIV Counselling and Testing. Health SA Gesondheid. 2016;21:86-95.

36. Agence d'information d'Afrique Centrale. Lutte contre les hépatites virales $B$ et $C$ : les médecins de Pointe-Noire souhaitent la mise en place d'un programme national. 2014. http://www.adiac-congo.com/content/ lutte-contre-les-hepatites-virales-b-et-c-les-medecins-de-pointe-noiresouhaitent-la-mise-3. Accessed 29 Jan 2016.

37. Ciupe SM, Ribeiro RM, Perelson AS. Antibody responses during hepatitis B viral infection. PLoS Comput Biol. 2014;10:e1003730.

38. Halliday J, Klenerman P, Barnes E. Vaccination for hepatitis C virus: closing in on an evasive target. Expert Rev Vaccines. 2011;10:659-72.

39. Lauer $\mathrm{GM}$. Immune responses to hepatitis $\mathrm{C}$ virus ( $\mathrm{HCV}$ ) infection and the prospects for an effective HCV vaccine or immunotherapies. J Infect Dis. 2013;207:57-12.

40. Leuridan E, Van Damme P. Hepatitis B and the need for a booster dose. Clin Infect Dis. 2011;53:68-75.

41. Hill A, Khoo S, Fortunak J, Simmons B, Ford N. Minimum costs for producing hepatitis $C$ direct-acting antivirals for use in large-scale treatment access programs in developing countries. Clin Infect Dis. 2014;58:928-36.

42. Rajbhandari R, Chung RT. Treatment of hepatitis B: a concise review. Clin Transl Gastroenterol. 2016;7:e190.

43. Angounda BM, Ngouloubi GH, Dzia AB, Boumba LMA, Baha W, Moukassa $D$, et al. Molecular characterization of hepatitis B virus among chronic hepatitis B patients from Pointe Noire, Republic of Congo. Infect Agent Cancer. 2016;11. http://infectagentscancer.biomedcentral.com/articles/10.1186/s13027-016-0088-3. Accessed 20 May 2017.

44. Angounda B, Bokilo Dzia A, Niama FR, Ahombo G, Mboumba LMA, Moukassa $D$, et al. Seroprevalence of markers and risk factors of hepatitis B virus among blood donors in Brazzaville. Congo Int J Innov Sci Res. 2016;20:171-9.

45. Luma HN, Eloumou SAFB, Malongue A, Temfack E, Noah DN, DonfackSontsa $\mathrm{O}$, et al. Characteristics of anti-hepatitis C virus antibody-positive patients in a hospital setting in Douala. Cameroon Int J Infect Dis. 2016:45:53-8.

46. Njouom R, Caron M, Besson G, Ndong-Atome G-R, Makuwa M, Pouillot R, et al. Phylogeography, risk factors and genetic history of hepatitis $C$ virus in Gabon. Central Africa. PLoS ONE. 2012;7:e42002.

47. Vannata B, Zucca E. Hepatitis C virus-associated B-cell non-hodgkin lymphomas. Hematology. 2014;2014:590-8.

48. Alidjinou EK, Moukassa D, Ebatetou-Ataboho E, Mahoungou GH, Pambou J-P, Sané F, et al. Higher levels of hepatitis C virus RNA found in blood donors co-infected with HIV as compared to HCV mono-infected donors. J Infect Dev Ctries. 2014;8. http://www.jidc.org/index.php/journal/article/ view/4767. Accessed 22 May 2017.

49. Dokekias EA, Okandze-Elenga JP, Gouary Kinkouna AS, Bokilo Dzia Lepfoundzou A, Garcia S. Séroprévalence de l'hépatite virale C chez les malades polytransfusés au CHU de Brazzaville. Bull Soc Pathol Exot. 2003;96:279-82.

50. Foupouapouognigni $Y$, Mba SAS, a Betsem EB, Rousset D, Froment A, Gessain $A$, et al. Hepatitis $B$ and $C$ virus infections in the three pygmy groups in Cameroon. J Clin Microbiol. 2011:49:737-40.

51. Dokekias EA, Okandze Elenga J, Manya Okanga D, Dzia-Lepfoundzou A. Prévalence des marqueurs viraux moyens chez les donneurs de sang à Brazzaville. Transf Clin Biol. 2001:8:84-9.

52. Erhabor O, Adias TC. Essentials of blood transfusion science. Author House UK. March 2013. pp 528.

53. Danic B, Bigey F. Les contre-indications au don du sang. Impact de l'arrêté du 12 janvier. Transfus Clin Biol. 2009;2009(16):209-13.

54. Prados Madrona D, Fernández Herrera MD, Al E. Women as whole blood donors: offers, donations and deferrals in the province of Huelva, southwestern Spain. Blood Transfus. 2014. http://www.bloodtransfusion.it/ articolo.aspx?idart=002601\&idriv=90. Accessed 4 June 2017.

55. Wambach K, Riordan J. Breastfeeding and human lactation. Burlington: Jones \& Bartlett Publishers, University of Kansas School of Nursing Karen Wambach; 2014. 
56. Dauar ET, Patavino GM, Mendrone Júnior A, Gualandro SFM, Sabino EC, de Almeida-Neto C. Risk factors for deferral due to low hematocrit and iron depletion among prospective blood donors in a Brazilian center. Rev Bras Hematol E Hemoter. 2015;37(5):306-15.

57. Organization Pan American Health. Eligibility for blood donation: recommendations for education and selection of prospective blood donors. Washington, DC: Pan American Health Organization; 2009.

58. Magoro T, Gachara G, Mavhandu L, Lum E, Kimbi HK, Ndip RN, et al. Serologic and genotypic characterization of hepatitis B virus in HIV-1 infected patients from South West and Littoral Regions of Cameroon. Virol J. 2016;13. http://virologyj.biomedcentral.com/articles/10.1186/s12985016-0636-x. Accesssed 22 May 2017.

59. Valente F, Lago BV, Castro CAV, Almeida AJ, Gomes SA, Soares CC. Epidemiology and molecular characterization of hepatitis B virus in Luanda. Angola. Mem Inst Oswaldo Cruz. 2010;105(8):970-7.

60. Iles JC, Abby Harrison GL, Lyons S, Djoko CF, Tamoufe U, Lebreton M, et al. Hepatitis C virus infections in the Democratic Republic of Congo exhibit a cohort effect. Infect Genet Evol. 2013;19:386-94.

61. Iles JC, Raghwani J, Harrison GLA, Pepin J, Djoko CF, Tamoufe U, et al. Phylogeography and epidemic history of hepatitis $C$ virus genotype 4 in Africa. Virology. 2014;464-465:233-43.

62. Iles JC, Njouom R, Foupouapouognigni Y, Bonsall D, Bowden R, Trebes A, et al. Characterization of hepatitis $C$ virus recombination in Cameroon by use of nonspecific next-generation sequencing. J Clin Microbiol. 2015;53:3155-64

63. Zeba M, Sanou M, Bisseye C, Kiba A, Nagalo B, Djigma F, et al. Characterisation of hepatitis $C$ virus genotype among blood donors at the regional blood transfusion centre of Ouagadougou, Burkina Faso. Blood Transfus. 2014;12:s54.

64. Chen SL, Morgan TR. The natural history of hepatitis C virus (HCV) infection. Int J Med Sci. 2006;3:47-52.

65. Westbrook RH, Dusheiko G. Natural history of hepatitis C. J Hepatol. 2014;61:S58-68.

66. Dzia-Lepfoundzou A, Angounda BM, Niama FR, Gambicky R, Oko APG, Okoko AR, et al. Suivi sérologique d'une cohorte d'enfants transfusés au CHU de Brazzaville, Congo. J Med Health Sci. 2017;18.

67. Bajpai M, Gupta E, Choudhary A. Hepatitis C virus: screening, diagnosis, and interpretation of laboratory assays. Asian J Transfus Sci. 2014;8:19.

68. Marwaha N, Sachdev S. Current testing strategies for hepatitis C virus infection in blood donors and the way forward. World J Gastroenterol. 2014;20:2948.

69. Rouet F, Deleplancque L, Mboumba BB, Sica J, Mouinga-Ondémé A, Liégeois F, et al. Usefulness of a fourth generation ELISA assay for the reliable identification of HCV infection in HIV-positive adults from Gabon (Central Africa). PLoS ONE. 2015;10:e0116975.

70. Ioniţă E, Lupulescu E, Alexandrescu V, Chiriţă C, Bălteanu M, Neguţ AE. False-positive ELISA reactions for the hepatitis $C$ virus and the human immunodeficiency virus after anti-influenzal vaccination. Bacteriol Virusol Parazitol Epidemiol Buchar Rom. 1990;1995(40):249-52.
71. Mullis CE, Laeyendecker O, Reynolds SJ, Ocama P, Quinn J, Boaz I, et al. High frequency of false-positive hepatitis $C$ virus enzyme-linked immunosorbent assay in Rakai, Uganda. Clin Infect Dis. 2013;57:1747-50.

72. Seale A, Broutet N, Narasimhan M. Assessing process, content, and politics in developing the global health sector strategy on sexually transmitted infections 2016-2021: implementation opportunities for policymakers. PLOS Med. 2017;14:e1002330.

73. WHO. Regional action plan for the implementation of the global health sector strategy on viral hepatitis 2017-2021 [Internet]. Cairo: WHO Regional Office for the Eastern Mediterranean: WHO; 2017 p. 34. Available from: http://apps.who.int/iris/bitstream/10665/258729/1/EMROPUB_2017_EN_19931.pdf.

74. FitzSimons D, Hendrickx G, Hallauer J, Larson H, Lavanchy D, Lodewyckx I, et al. Innovative sources for funding of viral hepatitis prevention and treatment in low- and middle-income countries: a roundtable meeting report. Hepatol Med Policy. 2016;1. http://hmap.biomedcentral.com/ articles/10.1186/s41124-016-0022-8. Accessed 29 May 2017.

75. WHO. By 2030, viral hepatitis to be eliminated from the African Region. Media Center;2016. http://www.afro.who.int/en/media-centre/pressreleases/item/8921-by-2030-viral-hepatitis-to-be-eliminated-fromthe-african-region.html.

76. Easterbrook PJ, Roberts T, Sands A, Peeling R. Diagnosis of viral hepatitis Curr Opin HIV AIDS. 2017;12:302-14

77. WHO. Global health sector strategies on HIV, viral hepatitis and sexually transmitted infections (STIs) 2016-2021. 2015.

78. WHO. Combating hepatitis $B$ and $C$ to reach elimination by 2030 . Geneva: WHO; 2016. p. 1-24. http://apps.who.int/iris/bitstream/10665/206453/1/ WHO_HIV_2016.04_eng.pdf.

79. Vox LE. Gouvernement annonce un programme national de lutte contre les hépatites. 2016. http://www.vox.cg/gouvernement-annonce-programme-national-de-lutte-contre-hepatites/. Accessed 29 Jan 2016.

80. Taty-Taty R, Yala F, Courouce AM, Arthaud ML, Saliou P, Biendo M, et al. [Carrier state for HBs antigen and $\mathrm{HBC}$ antibody in Brazzaville (congo): sero-epidemiological study in the hospital and nonhospital environment]. Bull Soc Pathol Exot. 1990;83:149-54.

81. Bossali F, Taty-Taty R, Houssissa P, N'suele W, Lingouala LG, Ontsira EN, et al. Séroprévalence de la coinfection hépatite $B$, hépatite $C$ et $\mathrm{VIH}$ chez des femmes accouchées à la maternité de l'hôpital Adolphe Sicé de PointeNoire en 2010. J Afr Hépatol Gastroentérol. 2012;6(4):315-9.

82. Bossali F, Koumou Okandze L, Katende S, Thouassa A. Séroprévalence de I'hépatite $B$ chez les malades atteints de cirrhose et des malades porteurs du carcinome hépatocellulaire à Pointe-Noire de 2005 à 2008. J Afr d'Hépato-Gastroentérologie 2011;5(1):2.

83. Makuwa M, Bakouetela J, Bassindikila A, Samba-Lefebvre. Étude des marqueurs sérologiques de l'hépatite $B$ chez les patients congolais testés pour l'infection à VIH. Médecine Afr. Noire. 1996:43.

\section{Submit your next manuscript to BioMed Central and we will help you at every step:}

- We accept pre-submission inquiries

- Our selector tool helps you to find the most relevant journal

- We provide round the clock customer support

- Convenient online submission

- Thorough peer review

- Inclusion in PubMed and all major indexing services

- Maximum visibility for your research

Submit your manuscript at www.biomedcentral.com/submit 